\title{
GLRX Gene
}

National Cancer Institute

\section{Source}

National Cancer Institute. GLRX Gene. NCI Thesaurus. Code C116580.

This gene plays a role in the reduction of glutathione-disulfides and glutathioneconjug ated proteins. 